beats be counted between the receipt of the radiotelegraphic message and the subsequent reports through the water and the air, the distance can be ascertained and checked, observing that an error of the beat means $4.40 \mathrm{ft}$. in air, but in water an error of one beat means an error of $1900 \mathrm{ft}$.

If sound signals could be implicitly relied on they would be a still greater aid to the seaman than they now are, for they are used at present both in air and water to warn vessels-in air by bells, guns, and sirens, and in water by submarine bells-but, unfortunately, they are not absolutely to be relied on, for experiment has shown that areas of silence occur sometimes in the vicinity of the localities where sound signals are emitted through the air, and that signals emitted through water may be deflected or reflected by obstruction. But further experiments are required before a definite opinion can be pronounced on their accuracy, and especially experiments on the rate of travel of sound through ocean water of different densities and temperatures. Experiments seem also to be needed in crowded thoroughfares as to whether sound-signals are or are not masked by more than one vessel emitting them. In addition, experiments are desirable with reference to the conveyance of sound through the water from shore stations: (I) What means should be taken to send the signal? (2) Will waves beating on the shore, especially on a rocky coast, interfere with the signal?

It is a great advantage to seamen that men of science should direct their attention to investigating problems of this nature, and it is to be hoped that Prof. Joly's work may cause the subject to be taken up and some further experiments made on the points which are still uncertain; but the book as it is is well worthy to be studied by all navigators.

It only remains to point out that it is a simple matter to draw a curve which will tell at a glance the distance from a station emitting simultaneous signals. If the beats of the watch be used as ordinates and tenths of miles as abscissæ, three curves can be drawn, one showing the distance off by the time elapsed between the flash of a gun, or the receipt of a radiotelegraphic signal, and the sound conveyed through the air; another, of the distance off by the time elapsed between the flash of a gun, or the receipt of a radiotelegraphic signal, and the sound conveyed through the water; and a third by the time elapsed between the two sounds, one conveyed by air, and the other by the water.

\section{PROF. T. G. BRODIE, F.R.S.}

$\mathrm{D}$ EEP regret is felt by many men of science at the death of Prof. Brodie, which occurred suddenly (from heart failure) at the early age of fifty on August 20. He was not only pre-eminent in the scientific world, but had endeared himself in a quite exceptional way to his numerous pupils, colleagues, and friends. The world is indeed poorer by his loss, and the tragic suddenness in No. 2445, Vor. 98 ] being cut off in his prime adds an unusual pathos to the event.

Prof. Brodie was born at Northampton, and was the second son of the Rev. A. Brodie, Vicar of Grandborough. He was educated at King's College School and St. John's College, Cambridge. He received his medical education at King's College, London, and after a brilliant academic career there and taking his degree of M.D. at the London University, he became demonstrator of physiology at his alma mater, and devoted his life thenceforth to this branch of science. He then became in turn senior demonstrator of physiology at the London Hospital and lecturer in the same subject at St. Thomas's Hospital. While still a student he commenced research work, and his earliest paper on Muscular Elasticity still remains authoritative. So closely was his name connected with original research, and so numerous were his papers on both the chemical and physical side of physiology, that when Prof. Sims Woodhead relinquished his directorship of the laboratories of the Royal Colleges of Surgeons and Physicians, London, for his chair at Cambridge, Brodie was immediately chosen as his successor, and he held the post with distinction and success until the Royal Colleges, as a measure of economy, decided to maintain their laboratories no longer. So fruitful had been the work carried out and inspired by Brodie in this position that in 1904 he received his F.R.S. Then came an interval in which Brodie filled simultaneously three posts-namely, the lectureship on physiology at the London School of Medicine for Women, the professorship of physiology at the Royal Veterinary College, and the professor superintendentship of the Brown Animal Sanatory Institute. This triple part meant overwhelmingly hard work, but it did not stop Brodie's researches, and it was only because each post was so poorly paid that it was necessary. England often treats her scientific sons thus, and it is much to be regretted that a man of such distinction should have been obliged to seek a position and salary worthy of his gifts in a colonial university. It was in 1908 that Brodie accepted the chair of physiology at Toronto, and London's loss was Canada's gain.

Prof. Brodie used to revisit London every long vacation, and during these so-called holidays he was always hard at work at research. It was during this time that his famous work on the kidney was carried out, and his Croonian lecture at the Royal Society dealt with one aspect of his investigations on this subject. Soon after the outbreak of war he became a captain in the Canadian medical service, and in this position undertook valuable research work on questions arising out of the war: such as respiratory effects, and the means of re-educating maimed men to become useful members of society.

As a teacher he was most successful; as a writer he was a little slow, but always sure and lucid; his unpublished manuscripts will be brought to light later; as a personal friend he was loyal, straightforward, and true. 
His widow and three fine sons survive to mourn his loss; his funeral at Hampstead on August 23. was a military one, and was largely attended not only by his relations and personal friends, but by representatives, military and medical, of both British and Canadian institutions.

\section{SCIENTIFIC AND INDUSTRIAL RESEARCH. ${ }^{1}$}

THE important Report before us embodies the first annual statement of the work of the Advisory Council. Its contents deserve the closest consideration by all who have been interesting themselves in the dominating questions of the organisation of scientific and industrial research. We hope to deal more in detail with the proposals and suggestions in the Report in a later issue. Meanwhile, it will be sufficient to point out that it is divided into sections which are occupied respectively with:-

(i) The statement of the problems at issue and the steps taken by the Advisory Council to inform itself as to the present condition of scientific research in the United Kingdom and the bodies or persons conducting it.

(ii) The standing committees appointed on special subjects and the co-operative action undertaken by trade associations and professional and learned societies.

(iii) The nature of the difficulties surrounding the organisation of scientific and industrial research.

(iv) The sphere of action of the universities and technical colleges and the probable necessity for special research institutions.

(v) The necessity for conjoint action by all portions of the Empire and a general statement of the conditions of successful work.

The general tone of the Report may be described as tentative; the Council evidently desiring to feel its way cautiously and yet desiring to utilise so far as possible at present the existing machinery of research.

Taken as a whole, the Report is a very able statement of the complexity of the questions awaiting solution, and its recommendations should receive the most careful thought from all who are concerned with scientific work, whether pure or applied.

The report occupies fifty-six pages, of which forty are devoted to the report of the Advisory Council, signed by the administrative chairman, Sir William McCormick. In an introductory note Lord Crewe refers to the establishment in July, 19I5, of the Committee of the Privy Council for Scientific and Industrial Research, and to grants made on the advice of the Advisory Council. Twenty scientific investigations of industrial importance, particulars of which are given in an appendix, have been aided; and, in addition, grants amounting at the close of the academic year 1916-I7 to about 6oool. have been made to individual research workers. The amount placed by Parliament at the disposal of the Committee for

1 Report of the Committee of the Privy Council for Scientific and Industrial Research for the Year 1915-1016. [Cd. 8336]. (London: Wyman and Sons, Ltd.) Price $3 d$.

No. 2445 , VOL. 98$]$ the establishment of the scheme was $25,000 l$. for the tinancial year $1915-16$, and of this 12,241 . was expended, including a grant of $425 \mathrm{ol}$. to the Royal society. For the current financial year the vote by Parliament is $40,000 l$.

A memorandum embodying certain suggestions for promoting co-operation between different parts of the Empire in the organisation of scientific and industrial research is printed as an appendix. Approval is expressed of the principle of Imperial co-operation; and it is suggested that each Overseas Government which is willing to enter into such an arrangement should constitute some body or agency having functions analogous to those of the Advisory Council which acts for the United Kingdom. The Committee of Council is prepared to co-operate with the Secretary of State in establishing and conducting any central organisation which it may be found desirable to set up in London for the purpose of facilitating and carrying on the business of an Imperial Scheme of Research.

The report of the Advisory Council opens with an historical statement in which reference is made to the establishment of the National Physical Laboratory, the Engineering Standards Committee, the Imperial Institute, the Imperial College of Science and Technology, and other national institutions. At the outset the Council decided to give science in its applications to industry precedence over pure science, though under no misapprehension as to the relations between pure and applied science. Conferences were held with a number of professional bodies, and standing committees were appointed on engineering, metallurgy, and mining, while others are contemplated. A register of researches is being prepared, and encouragement is being given to co-operative research to benefit an industry as a whole. The most promising sign of progress is the increased interest in scientific research now manifested by men of business, manufacturers, and trade associations, but much yet remains to be done on a larger scale than has hitherto been attempted. The small scale on which most British industrial firms have been planned is one of the principal impediments in the way of the organisation of research, with a view to the conduct of these long and complicated investigations which are necessary for the solution of the fundamental problems lying at the basis of our staple industries.

It is intended to issue, under the title of "Science and Industry," a new series of pamphlets showing among other matters what is being done in industrial research laboratories in the United States and elsewhere. One of these will include material collected by Mr. A. P. M. Fleming, and another the paper by Dr. C. E. Kenneth Mees, printed in Nature of July 13 and 20 . Some of the conditions to be secured if the object for which the Committee of Council was established is to be attained are summarised as follows :-

If we were asked to state these conditions in the shortest possible terms we should reply: First, a largely increased supply of competent researchers; secondly, a hearty spirit of co-operation among all concerned, men of science, men of business, working men, professional and scientific societies, universities and technical colleges, local authorities and Government departments. And neither condition will be effective without the other.

The first condition of success cannot be secured rapidly at any time, and for the moment is out of the question. It is often said that when the industries call for the research workers, they will be forthcoming. The demand will create a supply. No doubt it will in time, especially if the discoverer or inventor 